\title{
A Study of the Return Generated and Managerial Efficiency of Select Mutual Fund Schemes in India.
}

\author{
Soheli Ghose \\ Research Scholar (Ph.D Programme), Department of Commerce, Calcutta University, India.
}

\begin{abstract}
Indian Mutual Funds are playing a very crucial developmental role in allocating resources in the emerging market economy. Mutual funds act as a financial intermediary in fund mobilization and investment. The essence of a Mutual Fund is the diversified portfolio of investment which diversifies and reduces the risk by spreading out the investor's money across available or different types of investments. This study analyzes the behaviour of few selected Mutual Fund Schemes during the period of December 2008 to December 2012 in comparison to Sensex Return. I have also analysed the managerial efficiency in stock selection through Alpha, Beta and RSQ and their variability for each of these mutual funds in this period. It is generally believed that mutual funds are less volatile as the managers use their expertise in selecting the appropriate stocks for the mutual fund portfolio. The data is analyzed using Pearson's Product Moment Correlation Method, the coefficient of variation of the return generated by the Sensex and the Mutual Fund Schemes to determine a more stable series and ANOVA for the variation in Alpha, Beta and RSQ of the funds. It was found that in the given study period the variability in the return of the Mutual Fund Schemes are between moderate to high and thus these Mutual Fund Schemes may not be as stable as they seem to be and the fund managers were not so efficient in selecting stocks for all the funds. The investors should weigh their options carefully before deciding to invest in a Mutual Fund.
\end{abstract}

Key Words: Equity Diversified Mutual Fund Schemes, Managerial Efficiency, Sensex Return, Stock Selection Ability of Managers, Variability in return.

\section{Background Of The Study:}

According to the Association of Indian Mutual Fund Industry, "A Mutual Fund is a trust that pools the savings of a number of investors who share a common financial goal. The money thus collected is then invested in capital market instruments such as shares, debentures and other securities. The income earned through these investments and the capital appreciation realized is shared by the unit holders in the proportion to the number of units owned by them. Thus a mutual fund is the most suitable investment for the common man as it offers an opportunity to invest in a diversified professionally managed basket of securities at a relatively low cost." Mutual Funds provide the benefit of skilled portfolio management by professional managers, to small investors who otherwise can't afford such expertise or knowledge. In this way they further the process of financial intermediation and also provide depth to the market. This has made mutual fund investment very popular in recent times. The first Mutual Fund scheme was launched in India by UTI in 1964 and since then the industry has seen a lot of growth in terms of new Mutual Fund schemes and their returns. In the past decade, Indian Mutual Fund industry has seen en enormous quantitative growth. In March 1965 the AUM was INR 25 crore. As on $31^{\text {st }}$ March 2013 the total AUM was INR 702493.8 crore. The Gross Resource Mobilization has increased from INR 314706 crore in 2002-03 to INR 8859515 crore in 2010-11. The number of Mutual Fund Houses is increasing year after year. As on $31^{\text {st }}$ December 2012 there were 41 Fund Houses. According to their size the top five Mutual Fund Houses in India are HDFC MF, Reliance MF, ICICI Prudential MF, Birla Sunlife MF and UTI MF. These players control over half India's mutual fund business.

\section{Literature Review:}

Treynor (1965) [1] developed the Treynor Ratio that measures returns earned in excess of that which could have been earned on a risk less investment per each unit of market risk. The most prominent study by Sharpe (1966) [2] developed a composite measure of return and risks the Sharpe Ratio. He evaluated 34 openend mutual funds for the period 1944-63. The results depicted that good performance was associated with low expense ratio and not with the size. Jensen (1967) [3] derived a risk-adjusted measure of portfolio performance (Jensen's alpha) that estimates how much a manager's forecasting ability contributes to fund's returns. Fama (1972) [4] developed methods to distinguish observed return due to the ability to pick up the best securities at a given level of risk from that of predictions of price movements in the market. Shashikant $U$ (1993) [5] pointed out that money market mutual funds with low-risk and low return offered conservative investors a reliable investment avenue for short-term investment. Narasimhan and Vijayalakshmi (2001) [6] analysed the top 
holding of 76 mutual fund schemes from January 1998 to March 1999. The study showed that, 62 stocks were held in portfolio of several schemes, of which only 26 companies provided positive gains. The top holdings represented more than 90 percent of the total corpus in the case of 11 funds. The top holdings showed higher risk levels compared to the return. The correlation between portfolio stocks and diversification benefits was significant at one percent level for 30 pairs and at five percent level for 53 pairs. Badrinath (2008) [7] carried out a study on contra funds with a special emphasis on SBI Contra Fund and found that the performance of SBI Contra Fund was superior to that of the general equity diversified market. Swaminathan (2011) [8] analysed the performance of 130 open ended mutual fund schemes from April 2003 to March 2008. The results showed that the private sector schemes performed better than their public counterparts and growth schemes were the best schemes. Shitole and Thyagarajan (2012) [9] evaluated the performance of three AMCs, namely, ICICI Prudential AMC, HDFC AMC and Franklin Templeton AMC and opined that most funds were able to provide market related returns and many schemes outperformed their respective benchmark indices.

\section{Objectives Of The Study:}

In the study I have analysed how few selected Mutual Fund Schemes behave during the period of December 2008 to December 2012 in comparison to the Sensex return. Before 2008 the Indian Financial Market was flourishing at an accelerated pace and the adverse effect of the Global economic crunch was felt only towards the latter half of 2008. Thus we have chosen a time period of December 2008 to December 2012 to study these mutual funds during the international financial crisis to understand their behaviour in volatile markets. The objectives of this study are as follows:

1. To understand the correlation between return generated by the selected Mutual Fund Schemes and Sensex.

2. To study the coefficient of variation between the Sensex return and mutual fund return.

3. To understand the Managerial Efficiency of the selected Mutual Fund Schemes in stock selection by analysing Alpha, Beta \& RSQ.

4. To study the variation in Alpha Beta \& RSQ of the selected mutual funds.

\section{Data Source And Research Methodology:}

Data: Data have been obtained from the official websites of the different mutual fund houses, websites of Bombay Stock Exchange (BSE) and National Stock Exchange (NSE), AMFI, SEBI (website as well as SEBI Handbook of Statistics on Indian Securities Market), RBI (website as well as RBI Handbook of Statistics on Indian Economy), valueresearchonline (website as well as Mutual Fund Year Book 2008 to 2013, Mutual Fund Insight Magazine January 2008 to January 2013, Wealth Insight Magazine January 2008 to January 2013), Personal Finance Investment Workbook, various reports and articles published in financial dailies, finance based magazines and periodicals.

Sample: First a sample of top 50 ranked Equity Diversified Mutual Funds of the year 2008 was taken. This ranking was done by Valueresearch an authentic and popular Mutual Fund Research organization. From here 12 schemes were selected at random. After the selection it was observed that there are 2 Public Sector Schemes, 3 Foreign Sector Schemes and 7 Private Sector Schemes. They are DSPBR Equity, DSPBR Top 100 Equity Reg G, DWS Investment Opportunities Reg ( 3 Foreign Sector Schemes ), HDFC Growth, ICICI Pru Infrastructure, Kotak Opportunities, Reliance Growth, Reliance Regular Savings Equity G, Sundaram Select Midcap Reg G, Tata Equity PE G ( 7 Private Sector Schemes ), SBI (Magnum) Contra G, UTI Dividend Yield ( 2 Public Sector Schemes ).

Methodology: In the first part of the study analysis of the correlation between the percentage return of all the 12 Mutual Fund Schemes and the percentage return of the Sensex was done. The correlation between the $\log \left(\right.$ Return of period' $t$ '/ Return of period ' $t-1^{\prime}$ ) is also analysed. Here every quarter of the study period has been considered i.e. starting from the Quarter January 08 to March 08 and ending with the Quarter October 12 to December 12. The data is analyzed using Pearson's Product Moment Correlation (Bivariate) Method (at 5\% level of Significance, 2 tailed) to find whether there is any significant Correlation between the Sensex Return and return generated by the fund and the return generated by the company scrips over the study period. If the correlation coefficient $(r)$ is greater than 0.5 it is considered to be significant and the corresponding $p$ - value is less than 0.05 . The higher the p-value is the less significant is the correlation. The 2 tailed tests have been considered as we are analyzing the positive as well as the negative effect of the correlation. Coefficient of Variation of these funds return with the sensex return has also been studied. In the second part of the study tests have been carried out to see the efficiency of the manager in stock selection and diversification of the funds by analysing the Alpha, Beta and R Square of the funds over a period of January 2010 to December 2012. Here the risk free return rate has been taken as $8 \%$ which is the approximate Average rate of Public Provident Fund prevalent rates between 2005 and 2012. This has been considered as the study period lies within this time frame. The analysis of the means and standard deviation between the Alpha, Beta and R Square of the funds through 
ANOVA test between the individual funds across the chosen study period has also been done to see whether there is any statistically significant variation.

\section{Analysis And Inferences:}

\subsection{Analysis Of The Individual Mutual Fund Schemes Return With Sensex Return:}

Null Hypothesis HO: There is no correlation between Mutual Fund Returns and Sensex Return.

Alternate Hypothesis H1: There is correlation between Mutual Fund Returns and Sensex Return.

Here I have taken two types of return. In the first case we have done the analysis between Percentage Return generated by individual Mutual Fund Schemes and Sensex. In the second case we have taken the Log form of the return which is Log (Return of period't' / Return of period 't-1'). Thus Log (Return of period't' / Return of period' $t$-1') of both Sensex Return and Mutual Fund Schemes Return has been put to the test of Correlation. We have used Pearson's Correlation Coefficient test for the above analysis.

5.1.1) Here it is observed that there is a very high and significant correlation between the Percentage Sensex return and the Percentage return generated by each of the 12 Mutual Fund Schemes. Amongst the 12 Mutual Fund Schemes the highest correlation coefficient was found in Kotak Opportunities G (0.980) and Reliance Regular Savings Equity (0.979) and the lowest correlation coefficient was found in Sundaram Select Midcap Reg G (0.930) and DSPBR Equity (0.940). As we can see even the lowest value is quite significant. Thus the Sensex and thereby market fluctuations do affect the fund returns and the null hypothesis is rejected (Table 1.1). 5.1.2) In the second type of return calculation with "LOG" data also we can see a very significant correlation between the Sensex return and the return generated by the individual Mutual Fund Schemes. The rationale behind choosing the LOG Return is to smoothen out the strong fluctuations in the return pattern. Amongst the 12 Mutual Fund Schemes the highest correlation coefficient was found in Reliance Regular Savings Equity G (0.973) and ICICI Pru Infrastructure (0.971) and the lowest correlation coefficient was found in Sundaram Select Midcap Reg G (0.904) and DSPBR Equity (0.921). As we can see even the lowest value is quite significant. Thus in the above analysis it is evident that there is a very significant correlation between Percentage and Log Return of the Mutual Fund Schemes and Sensex Returns (Table 1.2)

\subsection{Analysis Of The Coefficient Of Variation Of Individual Mutual Fund Schemes Return With Sensex Return:}

Here I have analyzed the coefficient of variation of the Mutual Fund Schemes and compared it with the Sensex variation. It is also observed that the Mutual Fund Schemes had very high variability especially that of DSPBR Equity (coefficient of variation $=7336.9$ ), DWS Investment Opportunity (coefficient of variation = 8877.95), ICICI Pru Infrastructure (coefficient of variation $=3073.72$ ), Kotak Opportunities (coefficient of variation $=2429.11$ ). The following Mutual Fund Schemes had comparatively lower Coefficient of Variation, Sundaram Select Midcap Reg G (591.32) and UTI Dividend Yield (680.26). The Coefficient of Variation of Sensex was 2466.84. Thus in some cases (Both DSPBR Equity and DWS Investment Opportunities Reg G are Foreign Sector Mutual Fund Schemes) the Mutual Fund Schemes have a massive variability in their return as compared to the Sensex. However few of the sample funds have shown less variability like UTI Dividend Yield (Public Sector Mutual Fund Scheme) thereby becoming the more reliable and stable series as compared to the other Mutual Fund schemes analyzed in this study (Table 2).

\subsection{Study of the Fund Managers Efficiency in Selecting Stocks for the Portfolio and Diversification of the Funds.}

Tests to see the efficiency of the manager in stock selection and diversification of the funds have been done. The alpha measure recognizes the ability of the fund manager in superior stock picking. A positive alpha value signifies positive stock selection ability by the fund manager and a negative alpha value suggests poor stock selection by the fund manager. Beta measures the systematic risk associated with the fund which exists because of the variability in the market return. $R$ Square $\left(R^{2}\right)$, the coefficient of determination measures the extent of diversification which is used to reduce the degree of unique/systematic risk. The value ranges between 0 and 1. R Square value of 1 implies a completely diversified portfolio having zero unique risk. R Square and Beta help in understanding the relationship of the fund with its benchmark and the extent of market risk (Table $3)$.

It was observed that though in all the funds the RSQ was high indicating diversification to minimize Beta, the Alpha was negative in some funds. This indicated that the fund managers were not so efficient in selecting stocks for all the funds. This was probably because as the study period is during the global meltdown, it was difficult for the managers to predict the performance of a stock due to extreme fluctuation in the financial markets. 


\subsection{Analysis of Variance (ANOVA) between Alpha, Beta and R Square across the Funds}

Null Hypothesis Ho: There is no significant variation in the means and standard deviations of the Alpha/Beta/RSQ of the funds across the study period.

Alternate Hypothesis H1: There is significant variation in the means and standard deviations of the Alpha/Beta/RSQ of the funds across the study period.

5.4.1) In the case of Alpha, $p$ value was less than 0.05 thereby rejecting the Null Hypothesis that there is no significant difference in the variance of Alpha across the funds. Thus the Alpha is different across the funds. The highest Mean Alpha was seen in UTI Dividend Yield (7.77), making the fund managers stock selection the most effective in this case and the lowest in ICICI Pru Infrastructure (-2.71), making the fund managers stock selection the least effective in this case.

5.4.2) In the case of Beta, $p$ value was less than 0.05 thereby rejecting the Null Hypothesis that there is no significant difference in the variance of Beta across the funds. Thus the Beta is different across the funds. The highest Mean Beta thereby the highest Systematic Risk was seen in Sundaram Select Midcap Reg G (1.14) and the lowest in UTI Dividend Yield (0.78).

5.4.3) In the case of RSQ, p value was less than 0.05 thereby rejecting the Null Hypothesis that there is no significant difference in the variance of RSQ across the funds. Thus the RSQ is different across the funds. The highest Mean RSQ was seen in DSPRB Top 100 Equity Reg G and SBI ((Magnum)) Contra (0.96), making it the most diversified portfolio among the 12 funds studied here and the lowest in Sundaram Select Midcap Reg $\mathrm{G}(0.82)$, making it the least diversified portfolio in the sample studied.

Thus it can be inferred that there was significant variation in the Alpha, Beta and RSQ of the funds. It can also be said that UTI Dividend Yield is comparatively stable fund among the sample studied here in the context of the highest Mean Alpha and lowest Mean Beta. Its Mean RSQ was also moderate at 0.92. Thus the stock selection efficiency and diversification ability of the fund manager is better in this fund among the sample studied (Table 4).

\section{TABLES}

Table 1.1: Correlation between Mutual Fund Returns and Sensex Return (Percentage Data).

\begin{tabular}{|c|c|}
\hline & Sensex Percentage Return \\
\hline DSPBR Eq & 0.940 \\
\hline DSPBR Top 100 Eq Reg G & 0.977 \\
\hline DWS Investment Opportunity & 0.973 \\
\hline HDFC Growth & 0.968 \\
\hline ICICI Pru Infra & 0.971 \\
\hline Kotak Opportunity & 0.980 \\
\hline Reliance Growth & 0.970 \\
\hline Reliance Regular Savings Eq & 0.979 \\
\hline SBI (Magnum) Contra & 0.978 \\
\hline Sundaram Select Midcap Reg G & 0.930 \\
\hline Tata Eq PE & 0.958 \\
\hline UTI Div Yield & 0.949 \\
\hline
\end{tabular}

Table 1.2: Correlation between Mutual Fund Returns and Sensex Return (Log Data).

\begin{tabular}{|c|c|}
\hline & Sensex Log Return \\
\hline DSPBR Eq & 0.921 \\
\hline DSPBR Top 100 Eq Reg G & 0.969 \\
\hline DWS Inv Opportunity Reg G & 0.970 \\
\hline HDFC Growth & 0.965 \\
\hline ICICI Pru Infra & 0.971 \\
\hline Kotak Opportunity & 0.970 \\
\hline Reliance Growth & 0.958 \\
\hline Reliance Regular Savings Eq & 0.973 \\
\hline Sundaram Select Midcap Reg G & 0.904 \\
\hline TATA Eq PE & 0.948 \\
\hline SBI Magnum Contra & 0.970 \\
\hline UTI Div Yield & 0.945 \\
\hline
\end{tabular}


Table 2: Coefficient of Variation between Mutual Fund Returns and Sensex Return.

\begin{tabular}{|l|r|}
\hline & \multicolumn{2}{|c|}{ Coefficient of Variation } \\
\hline DSPBR Eq & 7336.90 \\
\hline DSPBR Top 100 Eq Reg G & 910.91 \\
\hline DWS Investment Opportunity & 8877.95 \\
\hline HDFC Growth & 943.48 \\
\hline ICICI Pru Infra & 3073.72 \\
\hline Kotak Opportunity & 2429.11 \\
\hline Reliance Growth & 1299.52 \\
\hline Reliance Regular Savings Eq & 1072.24 \\
\hline SBI (Magnum) Contra & 2309.68 \\
\hline Sundaram Select Midcap Reg G & 591.85 \\
\hline Tata Eq PE & 1221.32 \\
\hline UTI Div Yield & 680.26 \\
\hline Sensex & 2466.84 \\
\hline
\end{tabular}

Table 3: R Square, Alpha and Beta of the Mutual Fund Schemes.

\begin{tabular}{|c|c|c|c|}
\hline DSPBR Equity D & R Square & Alpha & Beta \\
\hline Jan 10 & 0.92 & 8.09 & 0.91 \\
\hline Dec 10 & 0.94 & 4.08 & 0.92 \\
\hline Jan 11 & 0.94 & 6.32 & 0.88 \\
\hline Dec 11 & 0.91 & 4.65 & 0.89 \\
\hline Jan 12 & 0.91 & 5.27 & 0.9 \\
\hline Dec 12 & 0.87 & 2.09 & 0.86 \\
\hline \multicolumn{4}{|c|}{ DSPBR Top 100 Equity Reg G } \\
\hline Jan 10 & 0.96 & 6.58 & 0.84 \\
\hline Dec 10 & 0.96 & 2.49 & 0.82 \\
\hline Jan 11 & 0.97 & 4.8 & 0.79 \\
\hline Dec 11 & 0.97 & 3.63 & 0.8 \\
\hline Jan 12 & 0.96 & 4.01 & 0.82 \\
\hline Dec 12 & 0.95 & 2.03 & 0.85 \\
\hline \multicolumn{4}{|c|}{ DWS Investment Oppor Reg } \\
\hline Jan 10 & 0.95 & 7.12 & 0.97 \\
\hline Dec 10 & 0.95 & 3.41 & 0.93 \\
\hline Jan 11 & 0.95 & -3.32 & 0.91 \\
\hline Dec 11 & 0.92 & -1.77 & 0.86 \\
\hline Jan 12 & 0.93 & -1.06 & 0.85 \\
\hline Dec 12 & 0.89 & -3.77 & 0.86 \\
\hline \multicolumn{4}{|l|}{ HDFC Growth } \\
\hline Jan 10 & 0.95 & 6.17 & 0.89 \\
\hline Dec 10 & 0.94 & 3.94 & 0.88 \\
\hline Jan 11 & 0.94 & 4.55 & 0.88 \\
\hline Dec 11 & 0.92 & 5.05 & 0.89 \\
\hline Jan 12 & 0.94 & 7.26 & 0.88 \\
\hline Dec 12 & 0.93 & 3.85 & 0.85 \\
\hline \multicolumn{4}{|l|}{ ICICI Pru Infra } \\
\hline Jan 10 & 0.94 & 6.8 & 1 \\
\hline Dec 10 & 0.95 & -3.78 & 0.95 \\
\hline Jan 11 & 0.95 & -3.42 & 0.94 \\
\hline Dec 11 & 0.95 & -5.47 & 0.85 \\
\hline Jan 12 & 0.94 & -4.48 & 0.87 \\
\hline Dec 12 & 0.92 & -5.87 & 0.95 \\
\hline \multicolumn{4}{|l|}{ Kotak Oppor G } \\
\hline Jan 10 & 0.93 & 4.07 & 1.05 \\
\hline Dec 10 & 0.94 & -2.21 & 1.02 \\
\hline Jan 11 & 0.95 & -0.27 & 1.01 \\
\hline Dec 11 & 0.92 & 2.14 & 0.97 \\
\hline Jan 12 & 0.92 & 2.79 & 0.95 \\
\hline Dec 12 & 0.93 & 1.24 & 0.84 \\
\hline \multicolumn{4}{|l|}{ SBI Magnum Contra } \\
\hline Jan 10 & 0.97 & 4.57 & 0.99 \\
\hline Dec 10 & 0.97 & -0.68 & 1 \\
\hline Jan 11 & 0.97 & -0.38 & 1 \\
\hline Dec 11 & 0.96 & -1.36 & 1.01 \\
\hline Jan 12 & 0.96 & -1.62 & 1 \\
\hline
\end{tabular}




\begin{tabular}{|c|c|c|c|}
\hline Dec 12 & 0.91 & -2.63 & 0.88 \\
\hline \multicolumn{4}{|c|}{ Reliance Growth } \\
\hline Jan 10 & 0.93 & 7.27 & 1.01 \\
\hline Dec 10 & 0.93 & 2.16 & 0.99 \\
\hline Jan 11 & 0.93 & 3.81 & 0.98 \\
\hline Dec 11 & 0.9 & 2.65 & 1.01 \\
\hline Jan 12 & 0.91 & 4.38 & 1.01 \\
\hline Dec 12 & 0.85 & 1.1 & 0.91 \\
\hline \multicolumn{4}{|c|}{ Reliance Regular Savings Eq } \\
\hline Jan 10 & 0.87 & 13.15 & 1.08 \\
\hline Dec 10 & 0.92 & 4 & 1.05 \\
\hline Jan 11 & 0.92 & 4.26 & 1.05 \\
\hline Dec 11 & 0.89 & 2.62 & 1.07 \\
\hline Jan 12 & 0.9 & 4.06 & 1.06 \\
\hline Dec 12 & 0.85 & 2.59 & 0.94 \\
\hline \multicolumn{4}{|c|}{ Sundaram Select Midcap Reg G } \\
\hline Jan 10 & 0.85 & 5.17 & 1.17 \\
\hline Dec 10 & 0.86 & 5.29 & 1.21 \\
\hline Jan 11 & 0.85 & 6.43 & 1.18 \\
\hline Dec 11 & 0.79 & 7.17 & 1.24 \\
\hline Jan 12 & 0.8 & 9.02 & 1.19 \\
\hline Dec 12 & 0.74 & 3.79 & 0.83 \\
\hline \multicolumn{4}{|c|}{ Tata Equity PE } \\
\hline Jan 10 & 0.93 & 9.94 & 1.03 \\
\hline Dec 10 & 0.94 & 3.68 & 1.02 \\
\hline Jan 11 & 0.94 & 5.58 & 1 \\
\hline Dec 11 & 0.91 & 5.56 & 0.96 \\
\hline Jan 12 & 0.92 & 6.88 & 0.95 \\
\hline Dec 12 & 0.89 & 0.32 & 0.87 \\
\hline \multicolumn{4}{|c|}{ UTI Dividend Yld } \\
\hline Jan 10 & 0.92 & 9.83 & 0.83 \\
\hline Dec 10 & 0.92 & 6.97 & 0.81 \\
\hline Jan 11 & 0.95 & 10.28 & 0.76 \\
\hline Dec 11 & 0.93 & 8.78 & 0.75 \\
\hline Jan 12 & 0.93 & 7.95 & 0.75 \\
\hline Dec 12 & 0.9 & 2.81 & 0.77 \\
\hline
\end{tabular}

Table 4: Interaction between R Square, Alpha and Beta of the Mutual Fund Schemes.

\begin{tabular}{|c|c|c|c|c|c|c|c|c|c|c|c|c|c|c|}
\hline & \multicolumn{12}{|c|}{ FUND } & & \\
\hline & $\begin{array}{c}\text { DS } \\
\text { PB } \\
\text { R } \\
\text { EQ } \\
1\end{array}$ & $\begin{array}{c}\text { DSPBR } \\
\text { TOP } \\
100 \mathrm{EQ} \\
\text { REG G } \\
2\end{array}$ & $\begin{array}{c}\text { DWS } \\
\text { INV } \\
\text { OPPO } \\
\text { R REG } \\
3\end{array}$ & $\begin{array}{l}\text { HDF } \\
\text { C } \\
\text { GRO } \\
\text { WT } \\
\text { H } 4\end{array}$ & $\begin{array}{l}\text { ICIC } \\
\text { I } \\
\text { PRU } \\
\text { INFR } \\
\text { A } 5\end{array}$ & $\begin{array}{c}\text { KOT } \\
\text { AK } \\
\text { OPP } \\
\text { OR G } \\
6\end{array}$ & $\begin{array}{c}\text { SBI } \\
\text { (MAGN } \\
\text { UM) } \\
\text { CONT } \\
\text { RA } 7\end{array}$ & $\begin{array}{c}\text { RELI } \\
\text { ANCE } \\
\text { GRO } \\
\text { WTH } \\
8\end{array}$ & $\begin{array}{c}\text { RELIANC } \\
\text { E } \\
\text { REGULA } \\
\text { R } \\
\text { SAVINGS } \\
\text { EQ 9 }\end{array}$ & $\begin{array}{c}\text { SUNDARA } \\
\text { M SELECT } \\
\text { MIDCAP } \\
\text { REG G } 10\end{array}$ & $\begin{array}{l}\text { TA } \\
\text { TA } \\
\text { EQ } \\
\text { PE } \\
11\end{array}$ & $\begin{array}{l}\text { UTI } \\
\text { DIV } \\
\text { YL } \\
\text { D 12 }\end{array}$ & & \\
\hline & $\begin{array}{c}\text { Me } \\
\text { an } \\
\pm \\
\text { SD }\end{array}$ &  & $\begin{array}{l}\text { Mean } \\
\pm \text { SD }\end{array}$ & $\begin{array}{c}\text { Mea } \\
\mathbf{n} \pm \\
\text { SD }\end{array}$ & $\begin{array}{l}\text { Mean } \\
\pm \text { SD }\end{array}$ & $\begin{array}{l}\text { Mean } \\
\pm \text { SD }\end{array}$ & $\begin{array}{c}\text { Mean } \pm \\
\text { SD }\end{array}$ & $\begin{array}{l}\text { Mean } \\
\pm \text { SD }\end{array}$ & Mean \pm SD & Mean \pm SD & $\begin{array}{c}\text { Mea } \\
\mathbf{n} \pm \\
\text { SD }\end{array}$ & $\begin{array}{l}\text { Mea } \\
\mathbf{n} \pm \\
\text { SD }\end{array}$ & $\begin{array}{l}\mathbf{P} \\
\mathbf{V} \\
\mathbf{A} \\
\mathbf{L} \\
\mathbf{U} \\
\mathbf{E}\end{array}$ & $\begin{array}{c}\text { SIG } \\
\text { NIF } \\
\text { ICA } \\
\text { NC } \\
\text { E }\end{array}$ \\
\hline $\begin{array}{c}\text { R } \\
\text { S } \\
\mathrm{q} \\
\mathrm{u} \\
\mathrm{ar} \\
\mathrm{e}\end{array}$ & $\begin{array}{c}0.9 \\
2 \pm \\
0.0 \\
3\end{array}$ & $\begin{array}{l}0.96 \pm \\
0.01\end{array}$ & $\begin{array}{c}0.93 \pm \\
0.02\end{array}$ & $\begin{array}{c}0.94 \\
\pm \\
0.01\end{array}$ & $\begin{array}{c}0.94 \pm \\
0.01\end{array}$ & $\begin{array}{c}0.93 \pm \\
0.01\end{array}$ & $\begin{array}{l}0.96 \pm \\
0.02\end{array}$ & $\begin{array}{c}0.91 \pm \\
0.03\end{array}$ & $0.89 \pm 0.03$ & $0.82 \pm 0.05$ & $\begin{array}{c}0.92 \\
\pm \\
0.02\end{array}$ & $\begin{array}{c}0.92 \\
\pm \\
0.02\end{array}$ & $\begin{array}{l}<0 \\
.0 \\
01\end{array}$ & $\mathrm{~S}$ \\
\hline $\begin{array}{l}\mathrm{A} \\
\mathrm{lp} \\
\mathrm{h} \\
\mathrm{a}\end{array}$ & $\begin{array}{c}5.0 \\
8 \pm \\
2.0 \\
4 \\
\end{array}$ & $\begin{array}{c}3.92 \pm \\
1.65\end{array}$ & $\begin{array}{l}0.1 \pm \\
4.28\end{array}$ & $\begin{array}{c}5.14 \\
\pm \\
1.34\end{array}$ & $\begin{array}{c}-2.7 \pm \\
4.75\end{array}$ & $\begin{array}{c}1.29 \pm \\
2.25\end{array}$ & $\begin{array}{c}-0.35 \pm \\
2.54\end{array}$ & $\begin{array}{c}3.56 \pm \\
2.16\end{array}$ & $5.11 \pm 4.01$ & $6.14 \pm 1.82$ & $\begin{array}{c}5.33 \\
\pm \\
3.21\end{array}$ & $\begin{array}{c}7.77 \\
\pm \\
2.71\end{array}$ & $\begin{array}{l}<0 \\
.0 \\
01\end{array}$ & $\mathrm{~S}$ \\
\hline $\begin{array}{l}\text { B } \\
\text { et } \\
\text { a }\end{array}$ & $\begin{array}{c}0.8 \\
9 \pm \\
0.0 \\
2\end{array}$ & $\begin{array}{c}0.82 \pm \\
0.02\end{array}$ & $\begin{array}{l}0.9 \pm \\
0.05\end{array}$ & $\begin{array}{c}0.88 \\
\pm \\
0.02\end{array}$ & $\begin{array}{c}0.93 \pm \\
0.06\end{array}$ & $\begin{array}{c}0.97 \pm \\
0.07\end{array}$ & $\begin{array}{l}0.98 \pm \\
0.05\end{array}$ & $\begin{array}{c}0.98 \pm \\
0.04\end{array}$ & $1.04 \pm 0.05$ & $1.14 \pm 0.15$ & $\begin{array}{c}0.97 \\
\pm \\
0.06\end{array}$ & $\begin{array}{c}0.78 \\
\pm \\
0.03\end{array}$ & $\begin{array}{l}<0 \\
.0 \\
01\end{array}$ & $S$ \\
\hline
\end{tabular}

\section{Conclusion:}

6.1) Analysis 1:

6.1.1) There is a statistically significant correlation between the Sensex return and the return generated by the individual Mutual Fund Schemes. The Sensex and thereby market fluctuations do affect the fund returns and the null hypothesis is rejected. 
6.1.2) In the second type of return calculation with "LOG" data also there is a statistically significant correlation between the Sensex return and the return generated by the individual Mutual Fund Schemes. The Sensex and thereby market fluctuations do affect the fund returns and the null hypothesis is rejected.

6.2) Analysis 2: In some cases the Mutual Fund Schemes have a massive variability in their return as compared to the Sensex. However few of the sample funds have shown less variability like UTI Dividend Yield (Public Sector Mutual Fund Scheme) thereby becoming the more reliable and stable series as compared to the other Mutual Fund schemes analyzed in this study. Thus one can say that in the given study period the variability in the return of the Mutual Fund Schemes are between moderate to high and thus these Mutual Fund Schemes may not be as stable as they seem to be. It was further observed that the Coefficient of Variation of the Public Sector Mutual Fund Schemes is comparatively less than the Private Sector Mutual Fund Schemes and the Sensex. The Coefficient of Variation of the Private Sector Mutual Fund Schemes is moderate (some of them have a coefficient less than that of Sensex and two of them have a slightly higher coefficient than the Sensex).

6.3) Analysis 3: It can be said that though in all the funds the RSQ was high indicating diversification to minimize Beta, the Alpha was negative in some funds (DWS Investment Opportunities Reg G, ICICI Pru Infrastructure, Kotak Opportunities G and SBI (Magnum) Contra G. This indicated that the fund managers were not so efficient in selecting stocks for all the funds.

6.4) Analysis 4: It can be inferred that there was significant variation in the Alpha, Beta and RSQ of the funds. It can also be said that UTI Dividend Yield is comparatively stable fund among the sample studied here in the context of the highest Mean Alpha and lowest Mean Beta. Its Mean RSQ was also moderate at 0.92. Thus the stock selection efficiency and diversification ability of the fund manager is better in this fund among the sample studied.

\section{Scope Of Further Research:}

Due to time and few inherent constraints, all aspects of the mutual funds could not be looked into exhaustively. The following areas could be considered as an extension of the present study.

1. A study can be undertaken to understand the impact of capital market scams on mutual fund investments.

2. The sample of mutual fund schemes \& companies can be increased.

3. An extension of the time period beyond 2012 can be done to further analyse the effect of the aftermath of the global financial crisis.

4. An analysis of Fund managers' strategy and an impact of change in fund manager can be done.

5. A study can be done on the similar analysis on debt funds and then comparing them with equity funds.

\section{References}

[1]. Treynor, How to Rate Management of Investment Funds, Harvard Business Review, 43 (1), January-February, 1965, 63-75.

[2]. Sharpe, Mutual Fund Performance, Journal of Business, 39, 1966, 119-138.

[3]. Jensen, The Performance of Mutual Funds in the Period 1945-1964, Journal of Finance, 23(2), 1968, 389-416.

[4]. Fama, Components of Investment Performance, Journal of Finance, 27, 1972, 551-567.

[5]. Shashikant, Accounting Policy and Practices of Mutual Funds: The Need for Standardization, Prajan, 24 (2), 1993, 91-102.

[6]. Narasimhan and Vijayalakshmi, Performance Analysis of Mutual Funds in India, Finance India, 15 (1), March, 2001, 155-174.

[7]. Badrinath, Contra Fund in India: A Quick Look, Portfolio Organizer, January, 2008, 31-34.

[8]. Swaminathan, Performance of Mutual Funds in India: a Comparative Study of Public and Private Sector Mutual Funds (New Delhi, Gyan Publishing House, 2011).

[9]. Shitole and Thyagarajan, Performance Evaluation of Mutual Funds in India (New Delhi, Adhyayan Publishers and Distributors, 2012). 